\title{
Optimizing semen production for artificial insemination in swine
}

\author{
B. Colenbrander ${ }^{1}$, H. Feitsma ${ }^{2}$ and H. J. Grooten ${ }^{3}$ \\ 'Department of Herd Health and Reproduction, Yalelaan 7, $3584 \mathrm{CL}$, Utrecht, The Netherlands; \\ ${ }^{2}$ Cooperative Pig Al-Centre, Vught. The Netherlands; and ${ }^{3}$ Cooperative Pig Al-Centre, Helden, \\ The Netherlands
}

\begin{abstract}
Efficient production of high quality semen is of major importance to artificial insemination (AI) organizations: The semen produced should be free of contagious organisms, be of high quality, have good storage properties, fertilizing capacity and be of high genetic value. The best approach to prevent the spreading of microorganisms via semen in the process of $\mathrm{AI}$ is to collect semen from boars free from specific diseases, for example pseudorabies virus or leptospirosis. Antibiotics are added to the semen to suppress proliferation of microorganisms or even reduce their number. Sperm production is influenced by many factors such as season, collection frequency, breed and age. The average number of sperm cells produced per boar per week can vary more than $30 \%$ within one $\mathrm{AI}$ station, depending on the breed. Boar selection and boar management markedly influence the efficiency of sperm production. Sperm quality should be evaluated by fertility results obtained at breeding farms related to both farrowing rate and litter size to ensure a good quality monitoring system. A quality control system should be established to provide maximum reliability to customers.
\end{abstract}

\section{Introduction}

Efficient production of high quality semen is of major importance to AI organizations. The major reason Al was introduced in most species was for the prevention and abolition of venereal diseases. By using healthy males and preventing contacts between males and females diseases like brucellosis in cattle or contagious equine metritis in horses can be successfully eradicated. The main reasons for using AI nowadays, generally, is the execution of breeding programmes: by extending semen, a large number of females can be inseminated by one specific male, for example, semen from one bull can be used to inseminate more than 100000 cows in one year. In swine, however, the number of females inseminated by one boar is still only 1000 per year (double insemination and re-insemination included).

The semen produced by a sire should fulfil the following requirements: (1) absence of contagious organisms, (2) high quantity (3) adequate storage ability, (4) good fertilizing capacity and (5) high genetic value. In addition the semen should be produced in a way that fulfils physiological and behavioural requirements of the animal. Governments may set regulations to meet these requirements, especially regarding disease control, while other goals are set by individual breeding companies themselves. In this review a number of these aspects will be discussed.

\section{Health Status}

Semen used for artificial insemination has a great potential for spreading infectious diseases. More females are inseminated by each boar compared with natural mating. In addition, the natural defence barrier of 
both the female vagina and cervical mucus is partly bypassed. However, dilution of semen produces a 5 to 20-fold decrease in the number of microorganisms in the insemination dose in pigs and reduces the risk of females receiving an infective dose. Moreover, the addition of antibiotics should suppress proliferation of microorganisms during storage or even reduce their number.

As discussed later, the most sensible approach for an $\mathrm{Al}$ station is to collect semen from boars that are free of specific pathogens. Some infections can be hard to detect in the semen and sometimes ejaculates from infected animals do not permanently contain the infective organism. In addition, the detection of pathogens in the ejaculate may be difficult owing to substances present in the ejaculate such as proteolytic enzymes or proteinase inhibitors which will hamper detection of infectious agents (Hare, 1985).

The ejaculate consists of sperm cells and seminal plasma, the fluid that is formed by the testes and accessory sex glands. Semen can be contaminated by microorganisms present in these organs or by microorganisms present in the urethra, preputial mucosa or the preputial diverticulum. In addition, contamination with blood or urine can be a potential source of infection. There is a serious risk of bacterial or viral contamination of semen introducing diseases into a herd. The best way to prevent this is to produce semen free of pathogens. An ejaculate will always contain a number of bacteria. Addition of antibiotics, therefore, is customary or even compulsory, and legally prescribed within the European Community (EEC, directive 90/429/EEC, 1990). The most appropriate way to produce pathogen-free semen is to ensure that boars and the AI station are free of specific diseases. Only healthy boars are allowed to enter an AI station, via a separate quarantine station to achieve this goal. Moreover, the health status of the boars is regularly monitored via blood and semen analysis. Nevertheless, infections can occur and, for example, seronegative boars may shed virus at the time of semen collection. The significance of some bacterial and.viral diseases will therefore be discussed.

\section{Viral diseases}

Pseudorabies or Aujeszky's disease. Pseudorabies or Aujeszky's disease is caused by a herpes virus. The virus seems to spread by airborne transmission or trade of infected animals (Christensen et al., 1990). The virus can cause reproductive failure in the female, such as stillbirth or abortion (Kluge and Mare, 1974). The virus may be shed via the semen (Medveczky and Szabo, 1981). However, it still has not been proved that this disease can be transmitted from virus shedding boars to females via AI.

In some countries the disease is endemic; other countries are free from this disease. Vaccination programmes are used in endemically infected areas in an attempt to eradicate the wild-type virus and to obtain a population free from Aujeszky's disease. For intracommunitary trade of semen in the European Community (EC), only boars that are free of GI-antibodies can be used for production of $\mathrm{Al}$ semen, although some countries accept only semen from completely seronegative animals. Regular blood sampling and serological examination provides adequate monitoring of the health status of the boars (Vannier, 1991).

Pig reproductive and respiratory syndrome. Pig reproductive and respiratory syndrome is caused by the Lelystad virus (Wensvoort et al., 1991). Among other effects, it induces abortion in sows and gilts. The boar may also be affected and show a depression in sperm quality (Feitsma et al., 1992; Ohlinger, 1992). There is some circumstantial evidence that transmission via semen is possible. However, only during acute viraemia and when the ejaculate is contaminated by blood, is spreading of the disease via $\mathrm{Al}$ possible, although unlikely (Ohlinger, 1992).

Porcine parvo. Porcine parvo virus may cause reproductive failure in swine, characterized by fetal death, often in the absence of clinical symptoms in sows. The disease is endemic worldwide and it can disturb spermatogenesis in the boar temporarily (Forman et al., 1977; Ogasa et al., 1978). The virus can be excreted in semen (Gradil et al., 1991). In some countries females are vaccinated routinely to prevent clinical symptoms. Boars are not vaccinated generally in The Netherlands, but are in some other countries.

Foot and mouth disease, swine vesicular disease virus and African swine fever. Foot and mouth disease, swine vesicular disease virus and African swine fever are viral diseases that are not proved to be transmitted via semen. However, owing to adequate sanitary rules and regulations, the diseases are not present in most countries or can be prevented from entering the Al station (Hare, 1985). 


\section{Bacterial diseases}

Brucellosis suis. Brucellosis suis can affect both male and female fertility in pigs and bacteria can be transmitted via the semen (Vandeplassche et al., 1967). This disease has been eradicated in many countries. To ensure that this disease is not spread via AI, boars are allowed to enter an AI station only if they originate from a Brucella-free population. In addition, a negative complement binding test $(<20 \mathrm{iu})$ or an agglutination test $(<30$ iu) is required before boars are admitted to the AI station (EEC directive 90/429/EEC, 1990). These compulsory tests, however, may provide false positive reactions as a result of crossreactions with antigens of Yersinia enterocolitica, Escherichia coli and Salmonella species (Akkermans and Hill, 1971; Deyoe, 1972). EEC rules should be adapted and a specific assay will have to be developed for adequate control of this disease.

Leptospirosis. Leptospirosis is a zoonosis that occurs in many mammalian species. Rats and mice are reservoirs of the disease. Infected animals shed large numbers of leptospiras in their urine and thereby contaminate water and soil in which leptospiras can survive for weeks. The disease affects pigs of all ages: although symptoms are mainly observed in the sow (abortion), the boar can be a potential problem as the leptospiras are present in the male genital tract and can be transmitted via the semen (Ellis ef al., 1986). The disease can be detected by a microscopic agglutination test. False negative results are frequently encountered. Boars can be treated with two injections of dihydrostreptomycin ( $25 \mathrm{mg} \mathrm{kg}^{-1}$ body weight) at an interval of two weeks. Nevertheless, a limited number of animals will not be cured. The addition of antibiotics to the semen can also be used successfully to prevent the spread of viable leptospiras via artificial insemination. An adequate dose is 500 iu streptomycin $\mathrm{ml}^{-1}$, present for a minimal period of $45 \mathrm{~min}$ at a temperature of at least $15^{\circ} \mathrm{C}$ (EEC, directive 90/429/EEC, Schoenberg and Brem, 1992).

Other microorganisms. Mycoplasma and Ureaplasma spp. can be present in boar semen (Hare, 1985). Mycoplasma spp. can bind to seminolipids present in the plasma membrane of the sperm cell (Lingwood et al., 1990; Gadella et al., 1992). The significance of these microorganisms in affecting reproductive performance in pigs is not known. Addition of antibiotics to the semen extender may prevent spreading of the infections via Al (Hare, 1985).

\section{Health management}

Requirements at entrance. Boars should come to a quarantine-barn only from farms with a specified health status, free from infectious diseases. There should be an adequate management system at these farms and absence of specific diseases such as Hog cholera, brucellosis and Aujesky's disease. Many countries in Western Europe are officially free from other important swine diseases such as African swine fever, foot and mouth disease and Trichinellosis.

Apart from reproductive performance as specified below, the boars to be delivered at the quarantine station have to meet the following requirements. Blood tests should be negative for Brucella suis (CBR < ICFT units), Swine fever (AGGL $<30 \mathrm{iu}$ ) and Aujeszky (GI negative). Animals should be vaccinated to prevent Aujeszky's disease, erysipelas and porcine parvo virus (Table 1). In some countries, where Aujeszky's disease is absent, vaccination is not permitted. Animals should also be free from parasites.

Special attention should be paid to the soundness of the locomotor system, especially the condition of the legs or abnormalities in this system could become one of the main reasons for slaughter.

\section{Sperm Production}

\section{Boar selection}

An examination of each boar is performed before admittance to ensure sufficient sperm production of the boars at the AI station. The boars should be clinically healthy and sound of constitution. The libido of the boar, ability to mount, ability for erection and the sperm quality are evaluated. Minimal requirements will vary among AI organizations, but will usually include progressive motility of spermatozoa (at least 
Table 1. Vaccination schedule and vaccination frequency for boars during the breeding period and during adulthood

\begin{tabular}{|c|c|c|c|c|c|c|}
\hline \multirow[b]{3}{*}{ Disease } & \multicolumn{6}{|c|}{ Schedule of vaccination } \\
\hline & \multicolumn{3}{|c|}{$\begin{array}{l}\text { Breeding farm } \\
\text { (weeks) }\end{array}$} & \multicolumn{2}{|c|}{$\begin{array}{c}\text { Quarantine } \\
\text { station (weeks) }\end{array}$} & \multirow{2}{*}{$\begin{array}{c}\mathrm{Al} \\
\text { station }\end{array}$} \\
\hline & 1st & 2nd & 3 rd & 1st & 2nd & \\
\hline Aujeszky & $10-12$ & $14-16$ & $20-26$ & 2 & 5 & Every 4 th month \\
\hline Erysipelas & 18 & 25 & - & - & - & Once per year \\
\hline Parvo & 26 & - & - & - & - & Situation dependent \\
\hline Influenza & - & - & - & 2 & 5 & Situation dependent \\
\hline Parasitism & 34 & - & - & 4 & - & Every 6 th month \\
\hline
\end{tabular}

Table 2. Reasons for nonadmittance of boars (117 of 398) at an AI station

\begin{tabular}{lcc}
\hline & \multicolumn{2}{c}{ Breed } \\
\cline { 2 - 3 } Reasons & York & Duroc $\times$ York \\
\hline Number rejected (\%) & $83(45 \%)$ & $34(16 \%)$ \\
$\quad$ lack of libido & 30 & 7 \\
sperm production & 43 & 16 \\
insufficient erection & 3 & 3 \\
other reasons & 7 & 8 \\
Total number & 186 & 212 \\
\hline
\end{tabular}

$60-70 \%$ ), sperm morphology (less than $20 \%$ abnormal sperm cells), total number of sperm cells in the ejaculate (29-48 $\times 10^{9}$ depending on age and ejaculation frequency) and storage ability ( $>60 \%$ progressively motile after $48 \mathrm{~h}$ ). In Denmark $8 \%$ of the boars are excluded because they do not meet these criteria (Danske Slagterier, 1987). In Holland 15-45\% are excluded for several reasons (Table 2).

\section{Standard production}

There is wide variation in sperm production, both qualitatively and quantitatively. Many factors are involved in sperm production. The influences of some factors such as season (Swierstra, 1970; Wetteman and Bazer, 1985), social environment (Hemsworth, 1982), nutrition (Kemp and den Hartog, 1989), breed and age (Kennedy and Wilkens, 1984) and testis size (Hemsworth et al., 1983) have been discussed by Colenbrander and Kemp (1990). There is a seasonal influence and sperm production decreases in the spring (Fig. 1).

Differences in sperm production between breeds can be remarkable within an Al station (Table 3). In this case, some of the factors just mentioned are similar for all animals present. Sperm production can be expressed as the number of sperm cells or as doses produced by a boar per year or per week. A standard dose contains $3 \times 10^{9}$ sperm cells, in which at least $70 \%$ of the cells are progressively motile. However, the estimate of sperm concentration can be influenced by the laboratory procedure (Woelders, 1991).

Efficiency of overall sperm production on a unit can be significantly improved if boars that have suboptimal sperm production are killed in time. Suboptimal production can be due to lack of libido. low 


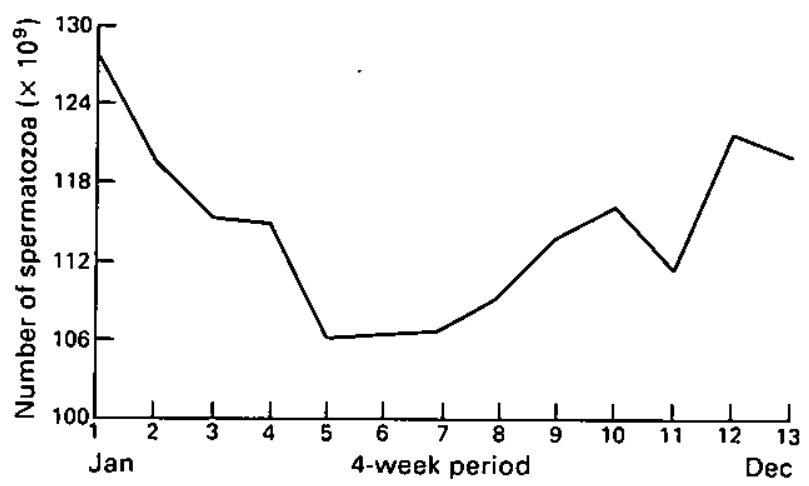

Fig. 1. Average weekly sperm production (over a 4 week period) of approximately 460 Yorkshire boars at an AI station during one year.

Table 3. Sperm production per breed at one AI station during 4 weeks in the spring (low seasonal production)

\begin{tabular}{lccc}
\hline Breed & $\begin{array}{c}\text { Number } \\
\text { of } \\
\text { boars }\end{array}$ & $\begin{array}{c}\text { Sperm cells } \\
\left(\times 10^{9}\right) \\
\text { per boar } \\
\text { per week }\end{array}$ & $\begin{array}{c}\text { Average } \\
\text { collection } \\
\text { frequency } \\
\text { per week }\end{array}$ \\
\hline $\begin{array}{l}\text { Dutch Landrace } \\
\text { Yorkshire sire line }\end{array}$ & 40 & 94 & 1.68 \\
Yorkshire sow line & 316 & 99 & 1.73 \\
Finnish Landrace & 49 & 107 & 1.44 \\
Duroc sire line & 25 & 105 & 1.31 \\
Crossbred & 6 & 80 & 1.63 \\
& 157 & 109 & 1.46 \\
\hline
\end{tabular}

sperm quantity or quality. Increasing ejaculation frequency from 1.2 to 2.0 times per week might have a positive effect on sperm quality, if sperm concentration is initially very high. Specific reasons for boar replacement and the frequency at which replacements occur are given (Table 4).

Efficiency of sperm production can be improved if ejaculates of terminal sires are mixed. The filling of bottles or tubes can be automated, which provides a more efficient use of labour. In addition, filling machines do not have to be cleaned between different ejaculates. When using mixed semen, fertility rate and litter size do not show a significant difference compared with those following the use of single ejaculates (Table 5).

\section{Quality control}

Bacteriology. Ideally the insemination doses produced by the AI station should be free from bacteria. This goal, however, cannot be achieved. Generally, the semen of the boar does not contain bacteria, but during ejaculation bacteria from the external genitalia, from the skin of the boar or from the sperm. collector will contaminate the ejaculate (Gradil ef al., 1991). Contamination can be significantly diminished by discarding the first jets of the ejaculate during collection.

Bacteria were cultured from fresh semen in $9 \%$ or $25 \%$ of 113 samples, in the presence of penicillin/. streptomycin or neomycin, respectively. The agents detected were Streptococcus spp., Staphylococcus spp... 
Table 4. Reasons for replacing boars at an $\mathrm{AI}$ station

\begin{tabular}{lcc}
\hline Reason & $\begin{array}{c}\text { Number of } \\
\text { boars }\end{array}$ & $\%$ \\
\hline Breeding strategy & 36 & 12 \\
genetic value & 18 & \\
hereditary defect & 1 &. \\
leg problems & 17 & \\
Sperm production & 189 & 61 \\
quality & 145 & \\
quantity & 27 & \\
libido/ejaculation & 17 & \\
Other & 84 & 27 \\
leg problems & 20 & \\
illness & 13 & \\
death & 20 & \\
aggressiveness & 6 & \\
other & 25 & \\
\hline
\end{tabular}

Table 5. Fertility data following artificial insemination (single insemination) using single ejaculates or mixed semen

\begin{tabular}{lccc}
\hline Semen type & $\begin{array}{c}\text { Number of sows } \\
\text { inseminated }\end{array}$ & $\begin{array}{c}\text { Farrowing rate } \\
(\%)\end{array}$ & $\begin{array}{c}\text { Litter size } \\
\text { (mean } \pm \text { SD) }\end{array}$ \\
\hline Single ejaculate & 5360 & 81.38 & $11.2 \pm 3.1$ \\
Mixed semen & 5083 & 81.59 & $11.2 \pm 3.0$ \\
\hline
\end{tabular}

Table 6. Fertility data related to natural mating and Al using semen after different storage periods

\begin{tabular}{lcccc}
\hline & $\ldots$ & \multicolumn{3}{c}{ Al storage time (h) } \\
\cline { 3 - 5 } Parameter & Natural & Fresh $<12$ & $18-26$ & $26-36$ \\
\hline & mating & & & \\
\hline Number of sows & 1529 & 8853 & 1419 & 1337 \\
Farrowing rate (\%) & 87.3 & 87.8 & 88.4 & 85.8 \\
Litter size & 11.3 & 11.7 & 11.7 & 11.1 \\
\hline
\end{tabular}

Pseudomonas spp. and also yeasts. The combination of neomycin and penicillin was most effective in extended semen.

Significant contamination can occur during the processing from ejaculate-to insemination dose. Containers in which the extender is produced and stored, or in which the ejaculate is diluted to its final concentration are sources of infection as are laboratory tables. 
Table 7. Fertility parameters during one year

\begin{tabular}{|c|c|c|c|c|}
\hline $\begin{array}{l}\text { Period } \\
\text { ( } 4 \text { weeks) }\end{array}$ & $\begin{array}{c}\text { Number of } \\
\text { sows } \\
\text { mated }\end{array}$ & $\begin{array}{l}\text { Animals not showing } \\
\text { oestrous symptoms } \\
\text { after mating } \\
(\%)\end{array}$ & $\begin{array}{c}\text { Farrowing } \\
\text { rate } \\
(\%)\end{array}$ & $\begin{array}{c}\text { Litter } \\
\text { size }\end{array}$ \\
\hline 01 (July) & 587 & 96.1 & 86.1 & 11.5 \\
\hline 02 & 629 & 95.5 & 85.6 & 11.5 \\
\hline 03 & 648 & 96.5 & 83.6 & 11.5 \\
\hline 04 & 684 & 96.2 & 85.2 & 11.9 \\
\hline 05 & 890 & 95.2 & 85.5 & 11.6 \\
\hline 06 & 982 & 94.9 & 90.2 & 11.4 \\
\hline 07 & 948 & 96.4 & 89.8 & 11.5 \\
\hline 08 & 1003 & 97.3 & 90.9 & 11.5 \\
\hline 09 & 1092 & 96.2 & 89.1 & 11.4 \\
\hline 10 & 1184 & 96.5 & 87.8 & 11.3 \\
\hline 11 & 1075 & 96.3 & 89.7 & 11.5 \\
\hline 12 & 1077 & 94.0 & 88.2 & 11.4 \\
\hline 13 (June) & 1236 & 95.0 & 86.4 & 11.6 \\
\hline
\end{tabular}

Insemination dose: $3 \times 10^{\circ}$ sperm cells per dose.

A routine procedure for monitoring the bacteriological contamination of ejaculate, extender, the direct environment in which the semen is processed and the equipment used is strongly recommended. Frequency of sampling may vary from twice a day for laboratory tables and equipment used to once daily for stored semen samples. The degree of bacteriological contamination influences sperm survival (Hare, 1985). In addition, pathogens in the insemination dose will infect the genital tract of the female. For intracommunity trade of boar semen in Europe the supplementation of antibiotics to the AI dose is obligatory. The combination of antibiotics used should be equal to the effect of 500 iu streptomycin, 500 iu penicillin, $150 \mu \mathrm{g}$ lincomycin and $300 \mu \mathrm{g}$ spectinomycin $\mathrm{ml}^{-1}$ when added and kept for $45 \mathrm{~min}$ at not less than $15^{\circ} \mathrm{C}$ (EEC, directive 90/429/EEC, 1990). Other antibiotics that are frequently used in decontaminating AI doses are: neomycin, gentamycin, kanamycin (Seth, 1991; Pedersen, 1991; Revell and Glossop. 1989). The addition of antibiotics in adequate concentrations and of adequate quality will promote sperm survival and increase fertility results (Revell and Glossop, 1989). However, aritibiotics can also be toxic and decrease sperm survival.

Sperm cell quality. Sperm cell quality should be routinely checked after storage for 24 or $48 \mathrm{~h}$. Motility and optionally morphology can be used as parameters. Fertility data should be satisfactory following Al, if semen is stored for less than $24 \mathrm{~h}$ (Table 6). Semen quality will gradually decline during long-term storage (2-5 days) (Weitze, 1991). A drop in farrowing rate ranging from 5 to $10 \%$ and in litter size up to $1.0 \mathrm{pig}$ per litter can be expected (Reed, 1991). This can be partly compensated for by increasing the insemination dose (Johnson et al., 1988).

The best parameters to use to gain insight into the quality of the sperm produced at the Al station will be the pregnancy rate that can be achieved following insemination and the farrowing rate and litter size later on. More farms now apply automated management systems to monitor the production efficiency at the farm. Al organizations can link into these systems and thus collect information on boar fertility. These systems are still being developed, but will finally provide information on, for example, fertility related to breed, age of spermatozoa, quality of spermatozoa, seasonal effects and insemination strategy (Table 7).

Fertility results can be markedly influenced by the handling of semen during transportation to and storage at the farm. Special attention should be paid to these factors, if fertility results are suboptimal on a specific farm. Other major factors such as oestrus detection and insemination strategy should also be considered. 


\section{Conclusion}

Semen quality is of significant importance for optimal results in pig reproduction. The AI station should supply the customer with semen doses with maximal fertilizing capacity and without the risk of disease transfer. A documented quality assurance system, inspected by independent authorities, may prevent failures and improve tracing and tracking of both semen and information and thus establish a controlled quality policy and provide maximum reliability to customers. This will put emphasis on preventative control measures and may reduce liability risks. The monitoring of sperm production of individual boars and the selection of boars for sperm quality will enable Al organizations to produce sperm doses efficiently and economically. Development of new 'in vitro' tests for sperm quality assessment and for prediction of fertilizing capacity would be of great value for optimizing boar selection and semen handling procedures. In addition, the use of computerized management programs at the AI station as well as on the farm and their linkage, may provide information for monitoring reproductive data and provide the possibility of detecting deviations and taking immediate action if results become suboptimal. Controlled sperm production, in combination with increased storage ability of semen, will stimulate the use of $\mathrm{AI}$ and ensure fertility results that match or exceed those achieved following natural mating.

\section{References}

Akkermans JPWM and Hill WKW (1971) Yersinia entercolitica serotype 9-infection als storend element bij de serologische diagnostiek van brucella infecties bij het varken Tijdschrift voor Diergeneesekunde 96 1654-1662

Christensen IS, Mousing J, Mortensen S, Soerensen KJ, Strandbygaard SB, Heariksen CA and Andersen JB (1990) Evidence of long distance aiborne transmission of Aujeszky's disease (pseudorabies) virus Veterinary Record $127471-474$

Colenbrander B and Kemp B (1990) Factors influencing semen quality in pigs founal of Reproduction and Fertility Supplement 40 105-115

Danske Slagterier (1987) Annual Report, National Committee for Pig Breeding. Heallin and Production pp 9-13. Copenhagen

Deyoe BL (1972) lmmunology and public health significance of swine brucellosis Joumal of American Velerinary Medicine Association $160640-643$

Ellis WA, McPariand PJ, Bryson DG and Cassells JA (1986) Boars as carriers of leptospiras of the Australis serogroup on farms with an abortion problem Velerinary Recond 118 563-566

Feitsma H, Grooten HJ, van Schie FW and Colenbrander B (1992) The effect of porcine epidemic abortion and respiratory syndrome (P.E.A.R.S.) on sperm production Proceedings of 12 th intentational Congress on Aninal Reproduction The Hague, Netherlands 4 1710-1712

Forman AJ, Lenghaus C. Hogg GG and Hate CJ (1977) Association of a parvo virus with an outbreak of foetal death and mummification in pigs Australian Veterinary joumal 53 326-329

Gadella BM. Colenbrander B, Van Colde LMG and LopesCardozo M (1992) Characterization of three arylsulfatases in semen: seminolipid sulfohydrolase activity is present in seminal plasma Biochimica et Biophysica Acta 1128 155-162

Gradil CM, Harding MJ, Molitor TW and Crabo B (1991) Boar semen: transmission and detection of viruses Reproduction in Domestic Animals Supplement 1 273-285

Hare WCD (1985) Diseases transmissible by semen and embryotransfer techniques. In Office International des Epizooties Technical Series, no. 4. Paris
Hemsworth PH (1982) Social environment and reproduction. In Control of Pig Reproduction pp 585-601 Eds DJA Cole and GR Foxcroft. Butterworth, London

Hemsworth PH, Windfield CG and Hansen C (1983) High mating frequency for boars: predicting the effect on sexual behaviour, fertility and fecundity Animal Production 37 409-413

Johnson LA, Aalbers JG and Grooten HJG (1988) Artificial insemination of swine: fecundity of boar semen stored in Beltsville TS (BTS), Modified Modena (MM), or MR-A and inseminated on one, three and four days after collection Zuchthygiene 23 49-55

Kemp B and den Hartog LA (1989) The influence of energy and protein intake on the reproductive performance of the breed. ing boar. A review Animal Reproduction Science 20 245-254

Kennedy BW and Wilkins JN (1984) Boar, breed and environmental factors influencing semen characteristics of boars used in artificial insemination Canadian joumal of Animal Science $64833-843$

Kluge JP and Mare CJ (1974) Swine pseudorabies: abortion, clinical disease and lesions in pregnant gilts infected with pseudorabies virus (Aujeszky's disease) American joumal of Veterinary Research 35 911-915

Lingwood CA, Quinn PA, Wilansky S, Nutikka A, Ruhnke HL and Miller RB (1990) Common sulfoglycolipid receptor for mycoplasmas involved in animal and human infertility Biology of Reproduction 43 694-697

Medvecaky I and Szabo I (1981) Isolation of Aujeszky's disease virus from boar semen Acta Veterinaria-Academiae Scientiarum Hungarica 29 29-35

Ogasa A, Yokoki Y, Fujisaka Y and Murakami Y (1978) Reproductive disorders in boars infected experimentally with porcine parvovirus Japanese Jounal of Animal Reproduction 24 73-76

Ohlinger VF (1992) The porcine reproductive and respiratory syndrome and its significance for artificial insemination in pigs. In Proceedings of 4 th Intemational Meeting of AI Vets pp I-4. Bonn, Germany

Pedersen PN (1991) The use of Al in Denmark Reproduction in Domestic Animals Stopplement 1 307-310 
Reed HC (1991) Commercial requirements for an effective fresh semen diluent Reproduction in Domestic Animals Supplement 1 255-270

Revell SG and Glossop CE (1989) A long time ambient temperature diluent for boar semen Animal Production 48 579-584

Schoenberg A and Brem S (1992) Leptospirosis in pigs with special references to treatment of boars with streptomycin according to directive $90 / 429 / \mathrm{EEC}$. In Proceedings of $4 \mathrm{th}$ Meeting of Al-vets 2.I pp 1-10. Bonn, Germany

Seth PC (1991) Swine A.l. in Canada Reproduction in Domestic Animals Supplement 1 303-305

Swierstra EE (1970) The effect of low ambient temperature on sperm production, epididymal sperm reserves and semen characteristics of boars Biology of Reproduction 2 23-28

Vandeplassche $\mathbf{M}$, Spincemaille J, Bouters $\mathbf{R}$, Dekeyser $\mathbf{P}$ and Bonte P (1967) Brucella suis infection and infertility in swine Mededilingen Verartsenjschool Gent 112
Vannier P (1991) Aujeszky's disease and pig artificial insemination. In Proceedings of Third International Meeting of AI Vets pp 1-9. Albi, France

Weitze KF (1991) Long-term storage of extended boar semen Reproduction in Domestic Animals Supplement 1 231-253

Wensvoort G, Terpstra C, Pol JMA, ter Laak EA, Blocmraad M, de Kluyver EP, Kragten C, van Buiten L, den Besten A, Wagenaar F, Broekhuijsen JM, Moonen PLJM, Zetstra T, de Boer EA, Tibben H], de Jong MF, van ' Veld P, Groenland GJR, van Gennep JA, Voets MT, Verheijden JHM and Braamskamp J (1991) Mystery swine disease in the Netherlands: the isolation of the Lelystad virus Veterinary Quarterly 13 121-134

Wetteman RP and Bazer FW (1985) Influence of environmental temperature on prolificacy in pigs journal of Reproduction and Fertility Supplement 33 199-208

Woelders H (1991) Overview of "in vitro" methods for evaluation of semen quality Reproduction in Domestic Animals Stuplement' 1 145-164 